\section{Development and pharmacolkinetic evaluation of chewable doxycycline tablets in Beagle dogs: comparison with a commercial formulation and evaluation of co-administration with vitamin supplement on the bioavailability}

\author{
Desenvolvimento e avaliação farmacocinética de comprimidos \\ mastigáveis de doxiciclina em cães Beagle: comparação com \\ uma formulação comercial e avaliação da coadministração com \\ suplemento vitamínico na biodisponibilidade
}

Isabela de Paula Lima' (1), Viviane de Souza Magalhães² (1), Rodrigo Machado de Oliveira' (1), Thais Paes Ferreira ${ }^{3}$ (D) , Gabriela Carmelinda Martins dos Santos ${ }^{4}$ (D), Melina Cardilo Campos Alves ${ }^{4}$ (D), Geraldo Augusto Pereira ${ }^{5}$ (D) , Fernanda Cristina Santos da Silva ${ }^{5}$ (D), Liliane Ferreira Rodrigues ${ }^{5}$ (D), Debora Azevedo Borges $^{7}$ (D) Priscila Cardim de Oliveira ${ }^{6}$ (D), Fabio Barbour Scott ${ }^{7}$ (1) \& Yara Peluso Cid ${ }^{8 *}$ (D)

${ }^{1}$ Industrial Chemistry, Departamento de Química Analítica (DQA), Instituto de Química (IQ), Universidade Federal Rural do Rio de Janeiro (UFRRJ), Campus Seropédica, RJ, Brazil.

${ }^{2}$ Pharmacist, DSc., Departamento de Parasitologia Animal (DPA), Instituto de Veterinária (IV), UFRRJ, Campus Seropédica, RJ, Brazil. ${ }^{3}$ Industrial Chemistry, MSc., DQA, IQ, UFRRJ, Seropédica, RJ, Brazil.

${ }^{4}$ Pharmacist, MSc. Programa de Pós-Graduação em Ciências Veterinárias (PPGCV), DPA, IV, UFRRJ, Campus Seropédica, RJ, Brazil.

5 Pharmacist, PPGCV, Departamento de Ciências Farmacêuticas (DCFar), ICBS, UFRRJ, Campus Seropédica, RJ, Brazil.

${ }^{6}$ Veterinarian, MSc., PPGCV, DPA, IV, UFRRJ, Campus Seropédica, RJ, Brazil.

${ }^{7}$ Veterinarian, DSc., DPA, IV, UFRRJ, Campus Seropédica, RJ, Brazil.

${ }^{8}$ Pharmacist, DSc., DCFar, ICBS, UFRRJ, Campus Seropédica, RJ, Brazil.

\begin{abstract}
Doxycycline (DOX) is the antibiotic of choice for the treatment of canine monocytic ehrlichiosis (CME), one of the main infectious diseases affecting dogs. Despite the therapeutic simplicity, the need for long-term use of DOX tablets (28 days) and gastrointestinal effects may pose problems. The aim of the study was to develop a DOX chewable tablet, evaluate its palatability and pharmacokinetic profile in comparison with a commercial formulation, Doxifin ${ }^{\circledast}$, and evaluate the influence of co-administration with vitamin supplement on the bioavailability of doxycycline. The AUC ${ }_{0 . \mathrm{v}}$ values found for DOX chewabletablets $(13.85 \pm 3.81 \mu \mathrm{g} \cdot \mathrm{h} / \mathrm{mL})$ and Doxifin ${ }^{\circledast}(15.88 \pm 4.38 \mu \mathrm{g} . \mathrm{h} / \mathrm{mL})$ did not differ significantly $(\mathrm{p}<0.05)$. The co-administration of the vitamin supplement Hemolitan ${ }^{\circledR}$ influenced the pharmacokinetic profile of DOX, leading to a decrease in bioavailability for chewable DOX tablets and Doxifin ${ }^{\oplus}$, with relative bioavailability values (F) of $64 \%$ and $62 \%$, respectively. Palatability evaluations confirmed the palatability of the chewable tablets. Therefore, a DOX chewable tablet is an important alternative that can overcome some of the challenges associated with the characteristic bitter taste of doxycycline, with considerable reduction animal stress, and with plasma doxycycline concentrations equivalent in practical terms to a conventional product.
\end{abstract}

Keywords: doxycycline, chewable tablets, palatability, pharmacokinetic.

\section{Resumo}

A doxiciclina (DOX) éo antibiótico escolhido para o tratamento da erliquiose monocítica canina (EMC), uma das principais doenças infecciosas que afetam os cães. Apesar da simplicidade terapêutica, a necessidade do uso prolongado de comprimidos de DOX (28 dias) e os efeitos gastrointestinais podem representar problemas. O objetivo do estudo foi desenvolver um comprimido para mastigar de DOX, avaliar sua palatabilidade e perfil farmacocinético em comparação com uma formulação comercial, Doxifin ${ }^{\circledast}$, e avaliar a influência da coadministração com suplemento vitamínico na biodisponibilidade da doxiciclina. Os valores de $\mathrm{AUC}_{\text {o-t }}$ encontrados para comprimidos mastigáveis de DOX $(13,85 \pm 3,81 \mu \mathrm{g} . \mathrm{h} / \mathrm{mL})$ e Doxifin ${ }^{\oplus}(15,88 \pm 4,38 \mu \mathrm{g} \cdot \mathrm{h} / \mathrm{mL})$ não diferiram significativamente $(p<0,05)$. A coadministração do suplemento vitamínico Hemolitan ${ }^{\circledast}$ influenciou o perfil farmacocinético, levando a uma diminuição da biodisponibilidade para comprimidos mastigáveis de DOX e Doxifin ${ }^{\circledast}$, com valores de biodisponibilidade relativa $(\mathrm{F})$ de $64 \%$ e $62 \%$, respectivamente. As avaliações da palatabilidade confirmaram que os comprimidos mastigáveis são palatáveis. Portanto, um comprimido para mastigar de DOX é uma alternativa importante que pode superar alguns dos desafios

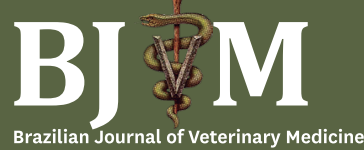

p-ISSN 0100-2430

e-ISSN 2527-2179

○
How to cite: Lima, I. P., Magalhães, V. S., Oliveira, R. M., Ferreira, T. P., Santos, G. C. M., Alves, M. C. C., Pereira, G. A., Silva, F. C. S., Rodrigues, L. F. Borges, D. A., Oliveira, P. C., Scott, F. B., \& Cid, Y. P. (2021). Development and pharmacokinetic evaluation of chewable doxycycline tablets in Beagle dogs: comparison with a commercial formulation and evaluation of co-administration with vitamin supplement on the bioavailability. Brazilian Journal of Veterinary Medicine, 43 , e002921. https://doi.org/10.29374/2527-2179. bjvm002921

Received: July 12, 2021.

Accepted: September 02, 2021

\section{*Correspondence}

Yara Peluso Cid

Departamento de Ciências Farmacêuticas, Instituto de Ciências Biológicas e da Saúde, Universidade Federal Rural do Rio de Janeiro - UFRRJ

Rodovia BR 465, Km 7, Campus Universitário, Zona Rural

CEP 23897-000 - Seropédica (RJ), Brasil

E-mail: yarapcid@gmail.com 
associados ao sabor amargo característico da doxiciclina, com considerável redução do estresse animal e com concentrações plasmáticas de doxiciclina equivalentes em termos práticos aum produto convencional.

Palavras-chave: doxicilina, comprimidos mastigáveis, palatabilidade, farmacocinética.

\section{Introduction}

Doxycycline (DOX), a broad-spectrum antibiotic belonging to the tetracycline group (Okerman et al., 2004), is the drug of choice for the treatment of canine monocytic ehrlichiosis (CME) (Villaescusa et al., 2015). CME, caused by Ehrlichia canis, an obligate intracellular bacterium, is an important tick-borne (Rhipicephalus sanguineus) disease (Rudoler et al., 2015), and has been identified as the main cause of morbidity and mortality in dogs worldwide (Skotarczak, 2003).

Despite the therapeutic simplicity of the use of tablets, some problems have been reported for DOX tablets, such as difficulty of administration over a long period (28 days) (Fourie et al., 2015; Rudoler et al., 2015; Villaescusa et al., 2015), palatability (Redelsperger et al., 2016; Sadrieh et al., 2005), and gastrointestinal effects (Rinaldi, 2014). An alternative to circumvent these difficulties is to use palatable chewable tablets to increase the voluntary administration of the drug (Song et al., 2016). The development of new veterinary pharmaceutical products should include formulations that can improve therapeutic efficacy while being affordable and easy to administer. In the Brazilian veterinary market, chewable doxycycline tablets are currently available (Doxygard ${ }^{\circledR}$, Doxymax ${ }^{\circledR}$ ), but their pharmacokinetic profile and palatability evaluation have not yet been reported.

The prescription of concurrent supplement therapy and DOX is common for canine patients. Therefore, it is important to evaluate the influence of the supplement on the absorption of DOX (KuKanich \& KuKanich, 2015). Hemolitan ${ }^{\circledR}$ is a supplement containing essential vitamins (B, K) and minerals (calcium, iron, zinc) to improve nutritional status. DOX absorption may be reduced by the presence of divalent or trivalent cations that chelate the drug, forming an inactive complex (Goodman, 2003; Monsalve et al., 2017).

The aim of the present study was to develop a chewable tablet containing doxycycline, evaluate its pharmacokinetic profile in comparison with a commercial formulation (Doxifin ${ }^{\circledR}$ ), and determine whether concurrent administration of a supplement (Hemolitan ${ }^{\circledR}$ ) and doxycycline reduces the relative bioavailability of doxycycline, as measured by traditional pharmacokinetic parameters.

\section{Material and methods}

\section{Chemicals}

Acetonitrile and methanol, both HPLC grade, as well as oxytetracycline (88.6\%) were purchased from Sigma-Aldrich (St. Louis, USA). Doxycycline hyclate (95.59\%) was purchased from Fragon (São Paulo, Brazil). Glycerin was purchased from Labsynth (São Paulo, Brazil). Gelatin powder, oxalic acid dihydrate P.A., glacial acetic acid and sodium acetate were purchased from Vetec Química Fina Ltda (Duque de Caxias, Brazil). Dog food was purchased from Invivo - Must Pet Food. Doxycycline tablets - Doxifin ${ }^{\circledR} 100 \mathrm{mg}$ (doxycycline hyclate enteric coated tablet), a topical anesthetic formulation $\left(\right.$ Emla $\left.^{\circledR}\right)$ and vitamin supplement $\left(\right.$ Hemolitan $\left.^{\circledR}\right)$ were purchased from local pet shops. Water used in the entire analysis was obtained using a Gehaka ultra purified system (Gehaka, São Paulo, Brazil).

\section{Preparation chewable tablets containing doxycycline}

Chewable doxycycline tablets were prepared at a dose of $100 \mathrm{mg}$ by mixing DOX hyclate (95.59\%) raw material with crushed and dry dog food, in the proportions of $6.25 \%$ and $70 \%$, respectively. In addition, bacon flavoring was added. This mixture was moistened with gelatin and glycerin gum. The final mass was distributed equally in small forms and kept under refrigeration. For palatability evaluations, a placebo formulation was also prepared.

\section{Physical-chemical evaluation of chewable tablets}

Weight variation was evaluated by weighing 20 tablets selected at random to determine their average weight. Then, the individual tablets were weighed and compared with the average weight. The determination of weight variation was performed for tablets > $250 \mathrm{mg}$ and with a 
variation of $\pm 5.0 \%$ for uncoated tablets. The formulation was evaluated according to the Brazilian Pharmacopeia (Brasil, 2019).

To test uniformity of content, 10 tablets were taken individually, weighed, crushed, and transferred to a volumetric flask containing acetic acid $4.5 \%(\mathrm{v} / \mathrm{v})$ as solvent. The solutions were filtered, diluted with aqueous oxalic acid solution ( $4 \mathrm{mM}, \mathrm{pH}=2.5)$, and analyzed by the LC-UV method.

The LC-UV system consisted of a Dionex Ultimate 3000 separation module coupled to a Dionex Ultimate 3000 UV-Vis detector (Dionex, California, USA). The chromatographic separation was performed using a Kromasil C18 column $(3.5 \mu \mathrm{m}, 4.6$ x $100 \mathrm{~mm})$ preceded by a Kromasil C18 guard column ( $3.5 \mu \mathrm{m}, 4.6 \times 10 \mathrm{~mm}$ ) (Tedia, Rio de Janeiro, Brazil), maintained at a constant temperature $\left(25 \pm 2^{\circ} \mathrm{C}\right)$. The mobile phase consisted of a mixture of acetonitrile:water adjusted to $\mathrm{pH} 2.5$ with oxalic acid $(75: 25 \mathrm{v} / \mathrm{v})$ with flow of $1.2 \mathrm{~mL} / \mathrm{min}$. The UV wavelength was set at $357 \mathrm{~nm}$ and the injection was $20 \mu \mathrm{L}$. The LC-UV system was controlled by the Chromeleon 6.8 software from Dionex.

\section{Pharmacokinetic studies}

\section{Animals and treatments}

Twenty-four Beagle dogs of both sexes, aged 2 to 6 years and with body weight between 9.3 and $13.4 \mathrm{~kg}$, were randomly divided into four groups of six animals each and housed individually in stalls two days before treatment. Clinical evaluations and hematological (hemoglobin, hematocrit and platelets) and biochemical (aspartate transaminase (AST), alanine transaminase (ALT), alkaline phosphatase (ALP), albumin and creatinine) examinations were performed prior to treatment (days -6 and 0) to ensure inclusion of only healthy animals in the studies. These evaluations were performed throughout the post-treatment evaluation period (days 1, 2 and 3) to monitor the health status of the animals.

The treatment was performed under fasting conditions with a single administration of doxycycline tablets (100mg), reaching an approached dose of $10 \mathrm{mg} / \mathrm{kg}$ of body weight. Groups (G1) and (G2) were treated with an intact commercial doxycycline tablet (Doxifin ${ }^{\circledR}$ ), in the absence and presence of the vitamin supplement (Hemolitan ${ }^{\circledR}$ ), respectively. Groups (G3) and (G4) were treated with an intact chewable doxycycline tablet in the absence and presence of Hemolitan ${ }^{\circledast}$, respectively.

To ensure animal welfare during the collection procedure, a topical anesthetic formulation $\left(E{ }^{\circledR}{ }^{\circledR}\right.$ ) was administered to the front paws (previously trichotomized) of each animal 30 minutes before each collection. The animals' blood was collected in EDTA tubes by cephalic venipuncture before and 30 minutes. 1, 2, 3, 4, 6, 8, 10 and 24 hours after administration. Plasma was obtained by centrifugation at $756 \mathrm{~g}$ for 10 minutes at $4^{\circ} \mathrm{C}$ and stored at $-20^{\circ} \mathrm{C}$ until analysis.

\section{Bioanalytical procedure}

\section{Preparation of standard solutions}

Solutions of doxycycline and oxytetracycline were prepared by dissolution in water adjusted to $\mathrm{pH} 2.5$ with oxalic acid to obtain a concentration of $1 \mathrm{mg} / \mathrm{mL}^{-1}$. The samples were stored at $4{ }^{\circ} \mathrm{C}$ protected from light. The solutions were stable under these conditions for 15 days. Doxycycline working standards at concentrations of 0.5, 1.0, 2.5, 5.0, 7.5 and $10.0 \mu \mathrm{g} / \mathrm{mL}$ were prepared for calibration and used to spike plasma. The oxytetracycline working standard was prepared at a final concentration of $1.0 \mu \mathrm{g} / \mathrm{mL}$.

\section{Preparation of calibration standards and quality control samples}

Blood samples were collected in EDTA tubes by cephalic venipuncture. These were centrifuged at $756 \mathrm{~g}$ for 10 min at $4^{\circ} \mathrm{C}$ and the plasma collected was stored at $-20^{\circ} \mathrm{C}$ until the assays. The plasma samples used for spiking and blanks were taken from experimental animals that were found to be free of tetracyclines. The calibration samples were prepared by spiking the stock solutions in blank plasma to get final serial concentrations of 0.5, 1.0, 2.5, 5.0, 7.5 and $10 \mu \mathrm{g} / \mathrm{mL}$. Quality control (QC) samples with concentrations of lower limit of quantification (LLOQ - $0.5 \mu \mathrm{g} / \mathrm{mL}$ ), low $(1.0 \mu \mathrm{g} / \mathrm{mL}$ ), 
medium $(2.5 \mu \mathrm{g} / \mathrm{mL}$ ), high $(7.5 \mu \mathrm{g} / \mathrm{mL}$ ) and upper limit of quantification (ULOQ - $10 \mu \mathrm{g} / \mathrm{mL}$ ) of standards were also prepared by the same procedure as the calibration standards. Oxytetracycline (IS) was added to all plasma samples at a concentration of $1.0 \mu \mathrm{g} / \mathrm{mL}$. Then the plasma was transferred directly to $2 \mathrm{~mL}$ Eppendorf tubes. The plasma samples were stored at the study site in a freezer at $-20^{\circ} \mathrm{C}$ until analysis.

\section{Sample preparation}

A volume of $50 \mu \mathrm{L}$ of sodium acetate buffer at $200 \mathrm{mM}$ (pH 6.8) was added to $0.5 \mathrm{~mL}$ of plasma and the mixture was shaken in a rotary shaker for $1 \mathrm{~min}$ before extraction. Then $1 \mathrm{~mL}$ of methanol was added to the plasma samples and vortexed for $1 \mathrm{~min}$, followed by centrifugation for $15 \mathrm{~min}$ at $756 \mathrm{~g}$. The mixture was then frozen at $-20^{\circ} \mathrm{C}$ for one day. The aqueous phase was frozen while the methanol layer, which remained liquid under these conditions, was transferred to a vial for direct injection into the LC column.

\section{Chromatography analysis}

The chromatographic separation was performed using a Kromasil C18 column $(3.5 \mu \mathrm{m}, 4.6 \times 100$ $\mathrm{mm}$ ) preceded by a Kromasil C18 guard column $(3.5 \mu \mathrm{m}, 4.6 \times 10 \mathrm{~mm})$ (Tedia, Rio de Janeiro, BR), both maintained at constant temperature $\left(30 \pm 2^{\circ} \mathrm{C}\right)$. The mobile phase consisted of acetonitrile: water adjusted to $\mathrm{pH} 2.5$ with oxalic acid $(2 \mathrm{O}: 80, \mathrm{v} / \mathrm{v})$ with a flow rate of $0.8-1.0 \mathrm{~mL} / \mathrm{min}$. The UV wavelength was set at $357 \mathrm{~nm}$ and the injection volume was $20 \mu \mathrm{L}$.

\section{Method validation}

The method was validated according to the guidelines of Brazil's National Sanitary Surveillance Agency (Brasil, 2012), to evaluate the following parameters: selectivity, matrix effect, residual effect, linearity, precision, accuracy and stability.

\section{Pharmacokinetic analysis}

The plasma concentration $v s$. time curves obtained after each treatment in individual animals were fitted with the PK solver program (Microsoft Excel ${ }^{\circledR}$ ). Pharmacokinetic parameters for each animal were analyzed using a non-compartmentalized mathematical model of extravascular administration. The maximum plasma concentration $\left(\mathrm{C}_{\max }\right)$ and time to reach maximum concentration $\left(\mathrm{t}_{\max }\right)$ were obtained from the plotted concentration time curve of each drug in each animal. The area under the plasma concentration versus time curve (AUC) from the time of dosing to Tlast (AUCO-tlast) was calculated by a linear up-log down trapezoidal method and extrapolated to infinity (AUCO-inf).

In order to evaluate the influence concurrent administration of supplement (Hemolitan ${ }^{\circledR}$ ) on bioavailability of DOX, relative bioavailability (F) of G2 and G4 were calculated with the treatments without the supplement as the reference, G1 and G3 respectively.

\section{Palatability evaluation}

Palatability evaluation (acceptance testing) was based on offering each dog a single dosing unit of chewable doxycycline tablet and placebo tablet. Twenty-four Beagle dogs, including males and females, with bodyweight of $11.3 \pm 2.3 \mathrm{~kg}$ (range 8 to $16.2 \mathrm{~kg}$ ) and aged $3.3 \pm 2.6$ years (range 1 to 8 years) were included in this study and were randomly divided into two groups of 12 animals per group. On each study day, acceptance test procedures were conducted at approximately the same time of day before feeding. Half of the dogs were treated with the chewable doxycycline tablet followed by a placebo tablet one day later; the other half of the dogs received a placebo tablet first and then chewable doxycycline tablet one day later. A sensory scale, with score from 40 to $100 \mathrm{~mm}$, for measurement of taste intensity for each dog was used as follows: (100) takes medication readily, (80) sniffs a while before taking medication, (60) shows reluctance to accept medication, (40) does not take medication at all. Scores 100 and 80 were considered as acceptance, while 60 and 40 as rejection. The mean and standard deviation were determined for each group. A total of 24 animals were needed to reach a power of $80 \%$ to demonstrate non-inferiority of the test formulation compared to placebo. 


\section{Statistical analysis}

Pharmacokinetic results are expressed as the mean \pm standard deviation (SD) and data were submitted to one way analysis of variance (ANOVA) followed by Tukey's multiple comparisons test (OriginPro 8 SRO version 8.0; OriginLab Corporation, Northampton, MA, USA). Palatability data were submitted to non-inferiority test using NCSS2021 software, version 20.0.2 (NCSS, LLC, Kaysville, Utah, USA, 2021). Statistical significance was set at 5\% ( $<<0.05)$ and with a non-inferiority margin of $20 \mathrm{~mm}$.

\section{Results}

\section{Physical-chemical evaluation of chewable doxycycline tablets}

The chewable doxycycline tablets were analyzed for softness and integrity characteristics. The mean weight $(1.7527 \mathrm{~g})$ reached the established criteria for uncoated tablets (Brasil, 2019) with none of the 20 individually weighed tablets outside of the variation range of $\pm 5.0 \%$ (1.6651-1.8403 g).

The uniformity of content assay demonstrated that the chewable doxycycline tablets were within the acceptable limit established by the Brazilian Pharmacopoeia (Brasil, 2019), exhibiting acceptance values (AV) of less than 15, thus demonstrating that the drug distribution in the formulation was homogeneous.

\section{Method validation}

The analytical procedures and LC analysis of DOX were validated and the results are shown in Table1. Selectivity was established since no significant interfering peak responses were observed at the retention time of DOX in spiked plasma samples. The method residual effect showed that the carryover in the blank samples following the ULOQ analysis was not higher than $20 \%$ of the analytes' signal of the LLOQ, and 5\% for the IS.

The CV of the IS-normalized MF (matrix effects) calculated from the eight matrix samples was not greater than 15\% (8.64\%). The linear regression line for DOX was evaluated in the range between 0.5 and $10 \mu \mathrm{g} / \mathrm{mL}$. Calibration data presented heteroscedasticity, so the calibration curves were subjected to weighted linear regression analysis using $1 / \mathrm{x}$ as the weighting factor. The calibration curve generated $(y=0.525 \mathrm{x}-0.048)$ using plasma as matrix showed a squared correlation coefficient of $>0.99$ for three days. The coefficient of variation (CV) was lower than to $20 \%$ relative to the nominal concentration for the LLOQ, and lower than to $15 \%$ relative to the nominal concentration of the other calibration standards. The inter-day precision of spiked standards of DOX at low, medium, and high levels showed coefficient of variation (CV) values that ranged from $6.32-12.40 \%$. Inter-accuracy ranged from $7.20-13.7 \%$. The limit of quantification (LOQ) of the analytical technique was $0.5 \mu \mathrm{g} / \mathrm{mL}$ (Table 1).

Table 1. Summary of linearity, matrix effect, accuracy and precision data.

\begin{tabular}{|c|c|c|c|c|c|c|c|c|}
\hline \multirow{3}{*}{$\begin{array}{l}\text { Amount spiked } \\
(\mu \mathrm{g} / \mathrm{mL})\end{array}$} & \multicolumn{3}{|c|}{ Linearity } & $\begin{array}{l}\text { Matrix } \\
\text { effect }\end{array}$ & \multicolumn{2}{|c|}{ Accuracy } & \multicolumn{2}{|c|}{ Precision } \\
\hline & \multicolumn{3}{|c|}{$(\% \mathrm{CV}) \mathrm{n}=5$} & \multirow{2}{*}{$(\% \mathrm{CV}) \mathrm{n}=8$} & \multicolumn{2}{|c|}{$(\% \mathrm{RSE}) \mathrm{n}=5$} & \multicolumn{2}{|c|}{$(\% \mathrm{CV}) \mathrm{n}=5$} \\
\hline & Day 1 & Day 2 & Day 3 & & Intra-assay & Inter-assay & Intra-assay & Inter-assay \\
\hline 0.5 (LLOQ) & 8.91 & 7.20 & 10.8 & --- & 8.79 & 7.20 & 8.91 & 10.8 \\
\hline 1.0 (Low QC) & 4.90 & 7.71 & 10.2 & 4.30 & 9.21 & 7.71 & 4.90 & 10.2 \\
\hline 2.5 (Medium QC) & 4.91 & 0.63 & 6.32 & --- & 12.2 & 13.7 & 4.91 & 6.32 \\
\hline 5.0 & 6.18 & 2.48 & 5.04 & --- & --- & --- & --- & --- \\
\hline 7.5 (High QC) & 8.23 & 13.7 & 12.4 & 8.64 & 11.3 & 12.2 & 8.23 & 12.4 \\
\hline 10.0 (ULOQ) & 2.31 & 2.23 & 4.63 & --- & --- & --- & --- & --- \\
\hline
\end{tabular}

CV: Coefficinet of variation; LLOQ: Low Limit of Quantification; Low QC: Low Quality Control; Medium QC: Medium Quality Control; High QC: High Quality Control; RSE: Relative Standard Error; ULOQ: Upper Limit of Quantification. 
The stability of spiked canine plasma samples showed acceptable results for all conditions tested. Post-processing stability was performed at 24 hours after extraction, freezing-thawing cycle stability was evaluated after three freeze and thaw cycles, short-term stability was evaluated after 24 hours and long-term stability was checked after storage at $-20^{\circ} \mathrm{C}$ for 1 and 2 months. Therefore, the samples were stable after storage and during the sample preparation procedures. The accuracy values for doxycycline at both QC levels in all stability studies were in the range of $\pm 15 \%$ of the nominal value and the $\% \mathrm{CV}$ was within $15 \%$.

\section{Pharmacolkinetic studies}

No adverse clinical reactions or significant changes in hematological (hemoglobin, hematocrit and platelets) and biochemical (aspartate transaminase (AST), alanine transaminase (ALT), alkaline phosphatase (ALP), albumin and creatinine) parameters were observed in any of the dogs submitted to any treatment throughout the period and were within the range of reference values described in the literature for adult dogs (Kaneko at al., 2008; Weiss \& Wardrop, 2010). No significant difference in the mean dose ( $\mathrm{mg} / \mathrm{kg}$ ) of doxycycline administered was observed between groups, with mean doses of $9.08 \pm 0.88 \mathrm{mg} / \mathrm{kg}$ (G1), $8.86 \pm 1.16 \mathrm{mg} / \mathrm{kg}$ (G2), $9.04 \pm 0.78 \mathrm{mg} / \mathrm{kg}$ (G3) and $8.83 \pm 0.79 \mathrm{mg} / \mathrm{kg}(\mathrm{G} 4)(\mathrm{p}<0.05)$. The curve of mean plasma concentration plotted against time for both formulations in absence and presence of vitamin supplement are shown in Figure 1.

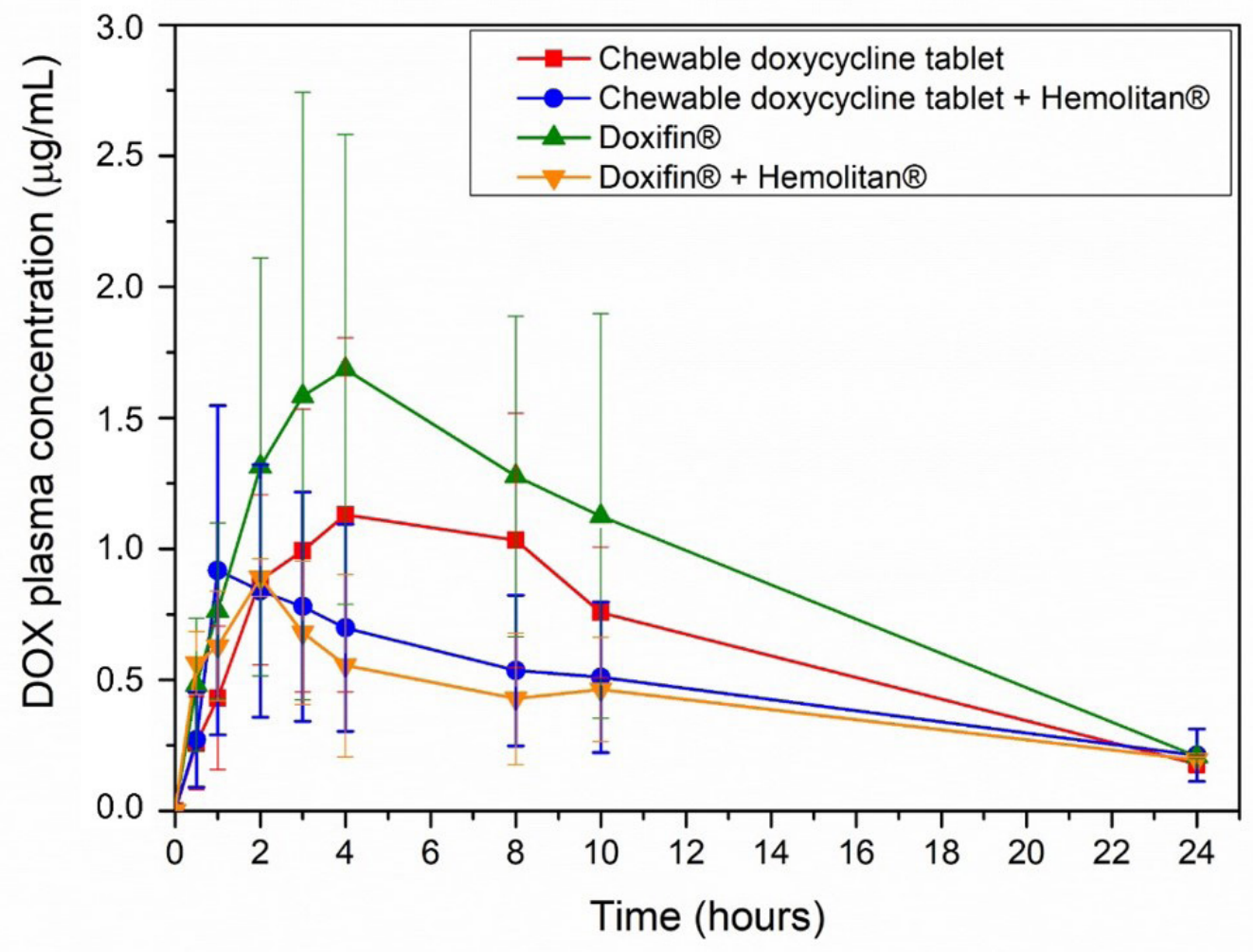

Figure 1. Mean plasma concentration curve of doxycycline versus time after oral administration of single dose of chewable doxycycline tablets and Doxifin ${ }^{\circledR}(10.0 \mathrm{mg} / \mathrm{kg})$ in the absence and presence of the vitamin supplement of Hemolitan ${ }^{\circledR}$ in dogs $(n=24)$.

Chewable doxycycline tablets demonstrated pharmacokinetic profile with rapid absorption, with $\mathrm{C}_{\max }$ of $0.97 \pm 0.34 \mu \mathrm{g} / \mathrm{mL}$ at $4.4 \pm 0.58$ hours $\left(\mathrm{t}_{\max }\right)$ and fast elimination $\left(\mathrm{t}_{1 / 2} 7.78 \pm 1.45\right.$ hours $)$. The same profile was observed for Doxifin ${ }^{\circledR}$, with $\mathrm{C}_{\max }$ of $1.53 \pm 0.88 \mu \mathrm{g} / \mathrm{mL}$ at $6.0 \pm 2.50\left(\mathrm{t}_{\max }\right)$ and $\mathrm{t}_{1 / 2}$ of $5.47 \pm 1.40$, with no significant difference for $\mathrm{C}_{\max }(\mathrm{p}=0.4771), \mathrm{t}_{\max }(\mathrm{p}=0.5562)$ or $\mathrm{t}_{1 / 2}$ $(\mathrm{p}=0.1902) . \mathrm{AUC}_{\mathrm{ot}}$ values did not differ significantly $(13.85 \pm 3.81 \mu \mathrm{g} . \mathrm{h} / \mathrm{mL}$ for chewable tablets and $15.88 \pm 4.38 \mu \mathrm{g} . \mathrm{h} / \mathrm{mL}$ for Doxifin $\left.{ }^{\oplus}\right)(\mathrm{p}=0.478)($ Table 2$)$. 
Table 2. Pharmacokinetic parameters of doxycycline following orally administration $(10 \mathrm{mg} / \mathrm{Kg})$ of chewable doxycycline tablet and comercial tablet $\left(\right.$ Doxifin $\left.^{\circledR}\right)$, both in the absence and presence of the vitamin supplement $\left(\right.$ Hemolitan $\left.^{\circledR}\right)$ to dogs $(\mathrm{n}=24)$.

\begin{tabular}{|c|c|c|c|c|}
\hline $\begin{array}{l}\text { Pharmacokinetics } \\
\text { parameters }\end{array}$ & $\begin{array}{l}\text { Chewable doxycycline } \\
\text { tablet }\end{array}$ & $\begin{array}{l}\text { Chewable doxycycline } \\
\text { tablet + Hemolitan }^{\circledR}\end{array}$ & Doxifin $^{\circledast}$ & Doxifin $^{\circledast}+$ Hemolitan $^{\circledast}$ \\
\hline $\mathrm{C}_{\max }(\mu \mathrm{g} / \mathrm{mL})$ & $0.97 \pm 0.34^{a}$ & $0.95 \pm 0.26^{a}$ & $1.53 \pm 0.88^{a}$ & $0.90 \pm 0.12^{\mathrm{a}}$ \\
\hline $\mathrm{t}_{\max }(\mathrm{h})$ & $4.40 \pm 0.58^{a}$ & $1.25 \pm 0.50^{b}$ & $6.00 \pm 2.50^{\mathrm{a}}$ & $2.25 \pm 1.26^{\mathrm{b}}$ \\
\hline $\mathrm{AUC}_{\mathrm{o-t}}(\mu \mathrm{g} \cdot \mathrm{h} / \mathrm{mL})$ & $13.85 \pm 3.81^{\mathrm{a}}$ & $8.94 \pm 3.14^{a}$ & $15.88 \pm 4.38^{\mathrm{a}}$ & $9.91 \pm 3.22^{\mathrm{a}}$ \\
\hline $\mathrm{AUC}_{0-\infty}(\mu \mathrm{g} \cdot \mathrm{h} / \mathrm{mL})$ & $15.84 \pm 3.10^{\mathrm{a}}$ & $12.17 \pm 3.28^{\mathrm{a}}$ & $18.45 \pm 6.05^{\mathrm{a}}$ & $13.72 \pm 1.71^{\mathrm{a}}$ \\
\hline$t_{1 / 2}(h)$ & $7.78 \pm 1.45^{\mathrm{a}}$ & $10.69 \pm 2.13^{b}$ & $5.47 \pm 1.40^{\mathrm{a}}$ & $14.11 \pm 4.66^{\mathrm{b}}$ \\
\hline Relative F (\%) & $\mathrm{N} / \mathrm{A}$ & $64.50 \pm 22.70$ & $\mathrm{~N} / \mathrm{A}$ & $62.40 \pm 20.30$ \\
\hline
\end{tabular}

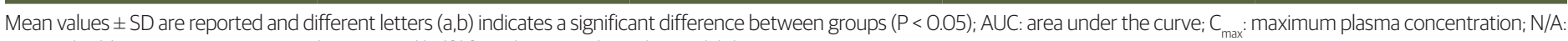
Not applicable; $\mathrm{t}_{\max }$ : time to $\mathrm{Cmax}_{\text {; }}$ and $\mathrm{t}_{\frac{1}{2}}$ : terminal half-life; Relative F: relative bioavailability.

Administration of the vitamin supplement Hemolitan ${ }^{\circledR}$ in combination with doxycycline led to a

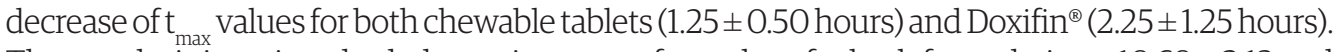
The co-administration also led to an increase of $\mathrm{t}_{1 / 2}$ values for both formulations, $10.69 \pm 2.13$ and $14.11 \pm 4.66$ hours for chewable tablets and Doxifin ${ }^{\circledR}$, respectively. $\mathrm{AUC}_{\mathrm{o}-\mathrm{t}}$ and $\mathrm{C}_{\max }$ did not differ significantly ( $p>0.05$ ) in the presence of the vitamin supplement for both formulations, but the association led to a decrease of bioavailability for chewable DOX tablets ( $\mathrm{F}=64 \%)$ and Doxifin ${ }^{\circledR}$ $(\mathrm{F}=62 \%)$ (Table 2$)$.

\section{Palatability evaluations}

The percentage of acceptance (scores 100 and 80) and the percentage of rejection (scores 60 and 40) for chewable doxycycline tablets and for placebo chewable tablets are displayed in Table 3. For the chewable DOX tablets the percentage of acceptance were $79.2 \%$ and for chewable placebo tablets it was 75\%. A higher percentage of dogs took the medication readily (score 100), 62.5\% for both DOX and placebo chewable tablets. A lower number of dogs sniffed a while before taking the medication (score 80), 16.6\% for DOX and $12.5 \%$ for placebo tablets. The percentage of rejection (scores 60 and 40 ) was $20.8 \%$ for DOX and $25 \%$ for placebo tablets. Non-inferiority test rejects the null hypothesis ( $p=0.00018$ ), at the $5 \%$ significance level with a tolerance margin of $20 \mathrm{~mm}$. The chewable DOX tablets can therefore be considered non-inferior to the chewable placebo tablets.

Table 3. Palatability evaluation of chewable doxycycline tablets and placebo chewable tablets.

\begin{tabular}{|c|c|c|c|c|c|c|}
\hline \multirow[b]{2}{*}{ Formulation } & \multirow[b]{2}{*}{ Score (mm) } & \multicolumn{2}{|c|}{ Acceptance } & \multicolumn{2}{|c|}{ Rejection } & \multirow[t]{2}{*}{ Mean sensorial score $(\mathrm{mm}) \pm \mathrm{SD}$} \\
\hline & & 100 & 80 & 60 & 40 & \\
\hline \multirow{2}{*}{ Doxycycline chewable tablets } & $\mathrm{n}^{\circ}$ animals/score & 15 & 4 & 4 & 1 & \multirow{2}{*}{$87.5 \pm 18.47$} \\
\hline & $\mathrm{N}(\%)$ & \multicolumn{2}{|c|}{$19(79.2 \%)$} & \multicolumn{2}{|c|}{$5(20.8 \%)$} & \\
\hline \multirow{3}{*}{ Placebo chewable tablets } & $\mathrm{n}^{\circ}$ animals/score & 15 & 3 & 6 & 0 & \multirow{3}{*}{$87.5 \pm 17.51$} \\
\hline & $\mathrm{N}(\%)$ & \multicolumn{2}{|c|}{$18(75 \%)$} & \multicolumn{2}{|c|}{$6(25 \%)$} & \\
\hline & Non-inferiority test* & \multicolumn{2}{|c|}{ p-value } & \multicolumn{2}{|c|}{0.00018} & \\
\hline
\end{tabular}

Score: (100) takes medication readily, (80) sniffs a while before taking medication, (60) shows reluctance in accepting medication, (40) not take medication at all. *Non-inferiority test was performed for sensorial score data (chewable doxycycline tablets and placebo chewable tablets) using NCSS2021, version 20.0.2 (NCSS, LLC, Kaysville, Utah, USA, 2021). Values showed noninferiority at the level of $\mathrm{p} \leq 0.05$ with a tolerance margin of $20 \mathrm{~mm}$.

\section{Discussion}

The developed and validated method was effective for pharmacokinetic evaluation, since it allowed DOX quantification in canine plasma up to 24 hours P.T. (Figure 1). Furthermore, the bioanalytical method assured quantifiable plasma levels in the blood until it reached $\mathrm{AUC}_{0-\mathrm{t}}>80 \%$ of $\mathrm{AUC}_{0-\infty^{\prime}}$ 
as recommended by the Guide for Tests of Relative Bioavailability/Bioequivalence of Medicines (Brasil, 2006). AUC of DOX for Doxifin $^{\circledast}$ and chewable tablets corresponded to 86.07 and $87.44 \%$, respectively, for $\mathrm{AUC}_{0-\infty}$

Drug plasma profile from dosage form studies is crucial to assess the performance of new formulations, since drug availability from the dosage form plays a critical role in a drug's clinical efficacy (Shargel \& Yu, 2004). Our results demonstrated that the chewable formulation did not influence the pharmacokinetic parameters of DOX when compared to swallowed tablet formulation $\left(\right.$ Doxifin $\left.^{\circledR}\right)$. Both formulations presented rapid absorption and elimination pharmacokinetic profiles, with no significant difference between any parameters evaluated.

The pharmacokinetic parameters for DOX administered orally in a single dose $(10 \mathrm{mg} / \mathrm{kg})$ have already been described by a few studies (Gutiérrez et al., 2012; KuKanich \& KuKanich, 2015). The values of $\mathrm{C}_{\max }(0.97 \pm 0.34$ and $1.53 \pm 0.88 \mu \mathrm{g} / \mathrm{mL})$ and $\mathrm{AUC}_{0-\mathrm{t}}(13.85 \pm 3.81$ and $15.88 \pm 4.38 \mu \mathrm{g} . \mathrm{h} / \mathrm{mL})$ obtained for chewable DOX tablets and Doxifin ${ }^{\circledR}$ in this study were lower them those reported by KuKanich \& KuKanich (2015) $\left(\mathrm{C}_{\max }=2.53 \mu \mathrm{g} / \mathrm{mL}\right.$ and $\left.\mathrm{AUC}_{\mathrm{ot}}=36.0 \mu \mathrm{g} \cdot \mathrm{h} / \mathrm{mL}\right)$ and Gutiérrez et al. (2012) $\left(C_{\max }=5.58 \pm 0.5 \mu \mathrm{g} / \mathrm{mL}\right.$ and $\left.\mathrm{AUC}_{\mathrm{o-t}}=70.33 \pm 6.23 \mu \mathrm{g} \cdot \mathrm{h} / \mathrm{mL}\right)$. Nevertheless, the values of $\mathrm{t}_{\max }\left(4.4 \pm 0.58\right.$ and $6.0 \pm 2.50$ hours) obtained for chewable DOX tablets and Doxifin ${ }^{\circledR}$ in this study were similar of those obtained by Gutiérrez et al. (2012) (tmax= $3.88 \pm 0.4$ hours) and higher than those reported by KuKanich \& KuKanich (2015) ( $t_{\max }=1.2$ hours). In contrast, the values of $\mathrm{t}_{1 / 2}$ ( $7.78 \pm 1.45$ and $5.47 \pm 1.40$ hours) obtained for chewable DOX tablets and Doxifin ${ }^{\circledR}$ in this study were lower than those obtained by Gutiérrez et al. (2012) ( $\mathrm{t}_{1 / 2}=5.59 \pm 0.03$ hours) and similar to those reported by KuKanich \& KuKanich (2015) ( $\mathrm{t}_{1 / 2}=5.59$ hours). Ruiz et al. (2014), using a higher dose $(20 \mathrm{mg} / \mathrm{kg})$ also found higher values of $\mathrm{C}_{\max }(2.03 \pm 0.28 \mu \mathrm{g} / \mathrm{mL})$ and $\mathrm{AUC}_{0-\mathrm{t}}$ $(22.1 \pm 2.52 \mu \mathrm{g} . \mathrm{h} / \mathrm{mL})$. However, $\mathrm{t}_{\max }(2.03 \pm 0.28$ hours $)$ and $\mathrm{t}_{1 / 2}=7.54 \pm 0.17$ hours $)$ were similar to this study. Differences in experimental conditions, such as breed, dose, dosage form, sampling and analytical method can explain the differences obtained between studies, leading to inconsistent comparison (Cerkvenik Flajs \& Grabnar, 2002). Moreover, gender could be a significant covariate for some pharmacokinetic parameters such as CL and V (Hopkins et al., 2017) and its influence should be evaluated.

DOX absorption can be reduced by the presence of divalent or trivalent cations that chelate the drug, forming an inactive complex (Goodman, 2003; Monsalve et al., 2017). Although international guidelines for the treatment of canine ehrlichiosis and anaplasmosis state that the combined administration of doxycycline with vitamin supplements is not recommended (Neer et al., 2002; Sainz et al., 2015), the prescription of supplement therapy and DOX concurrently is common for canine patients.

Our results do not corroborate those reported KuKanich \& KuKanich (2015), who reported that the concurrent oral administration of DOX with sucralfate suspension led to a delay of $\mathrm{t}_{\text {max }}$. In contrast, the $\mathrm{t}_{\max }$ values ( $1.25 \pm 0.50$ and $2.25 \pm 1.25$ hours) obtained for chewable DOX tablets and Doxifin ${ }^{\circledR}$ in this study were significantly in advance in dogs receiving DOX with concurrent Hemolitan ${ }^{\oplus}$. Although $\mathrm{AUC}_{0-\mathrm{t}}$ and $\mathrm{C}_{\max }$ did not differ significantly $(\mathrm{p}<0.05)$ in the presence of the vitamin supplement for both formulations, the association led to a decrease in bioavailability for chewable DOX tablets and Doxifin ${ }^{\circledR}$, with relative bioavailability values (F) of $64 \%$ and $62 \%$, respectively, corroborating the findings of KuKanich \& KuKanich (2015), who reported that concurrent oral administration of DOX with sucralfate suspension led to a decrease in bioavailability $(\mathrm{F}=20 \%)$.

Chewable tablets, since they are mechanically disintegrated in the animal's mouth during chewing, need to have enough attractions to be accepted by the animal, such as smell, taste and appearance. An oral formulation accepted by animals favors voluntary administration, reducing the stress on the animal at the time of administration (Song et al., 2016). Palatability evaluations are extremely important, since this is a determining feature of treatment adherence and consequently improves therapeutic efficacy, in particular in relation to oral antimicrobial therapy in dogs (Payne-Johnson et al., 2007). While doxycycline has a bitter taste (Hojman et al., 2007), the palatability evaluation demonstrated that chewable DOX tablets were accepted by the majority of dogs and was not inferior to placebo chewable tablets. Although there is no standard definition of palatability, for pharmaceutical products, consumption should be considered a measure of primary importance, so that acceptance tests are one of the best choices for palatability 
evaluations for dogs (Thombre, 2004). The intention of all animals to receive all formulations enables carrying out the intra-animal comparisons, i.e., characteristics such as sex and age are eliminated as variables that could influence acceptance of the medication, allowing a more careful assessment of the proposed formulation. However, more studies should be performed, since palatability results obtained strictly with laboratory dogs may not correlate well with the actual situation of pets in homes (Thombre, 2004).

The proposed formulation consists of an easy-to-prepare alternative, which can be produced on a small scale in magistral pharmacies allowing the individualization of the dose. The palatability results suggest that there will be no problems to dogs adhere to treatment. Since the bioavailability of the proposed formulation did not differ significantly from commercial tablets, Doxifin ${ }^{\circledR}$, the therapeutic efficacy would probably not be affected. However, efficacy evaluations must be carried out to confirm this claim.

\section{Conclusions}

The results of this study indicate that a chewable tablet containing doxycycline can overcome some of the challenges associated with the drug's bitter taste, with considerable reduction of animal stress, and with plasma doxycycline concentrations equivalent in practical terms to a conventional doxycycline product. Moreover, they show that the co-administration of the vitamin supplement Hemolitan ${ }^{\circledR}$ influenced the pharmacokinetic profile of DOX, leading to a decrease in bioavailability.

\section{Acknowledgements}

This study was supported by Fundação de Apoio à Pesquisa Tecnológica da Universidade Federal Rural do Rio de Janeiro (FAPUR), Fundação de Apoio a Pesquisa do Estado do Rio de Janeiro (FAPERJ) and Coordenação de Aperfeiçoamento de Pessoal de Nível Superior (CAPES). We also thank the Conselho Nacional de Desenvolvimento Científico e Tecnológico (CNPq) for the Scientific Productivity Grants of Professor Scott, F.B.

\section{Ethics statement}

The authors declare that the experiments were conduct following the animal welfare and ethics protocols.

\section{Financial support}

IPL, GCMS, MCCA, DAB, PCO - Received scholarship from CAPES (Coordenação de Aperfeiçoamento de Pessoal de Nível Superior). FBS - Received scholarship from CNPq (Conselho Nacional de Desenvolvimento Científico e Tecnológico). RMO, GAP, FCSS, LFR - Received scholarship from FAPUR (Fundação de Apoio à Pesquisa Científica e Tecnológica da UFRRJ). VSM, TFP, YPC - none.

\section{Conflict of interests}

The authors declare that there is no conflict of interest.

\section{Authors' contributions}

The development of the study and manuscript was carried out in collaboration with multidisciplinary professionals, aiming to meet all the demands of the project under the supervision of Professor Yara Peluso Cid. The development and characterization of the chewable tablets were carried out by Rodrigo Machado de Oliveira, Fernanda Cristina Santos da Silva and Liliane Ferreira Rodrigues. The analytical and bioanalytical procedures were carried out by Isabela de Paula Lima and Thais Paes Ferreira. Pharmacokinectics studies were carried out by Geraldo Augusto Pereira, Melina Cardilo Campos Alves, Debora Azevedo Borges and Priscila Cardim de Oliveira with the Supervision of professor Fabio Barbour Scott. The pharmacokinectics analysis were carried out by Gabriela Carmelinda Martins dos Santos and Viviane de Souza Magalhães. 


\section{Availability of complementary results}

The data that support the findings of this study are available from the corresponding author upon reasonable request.

The study was carried out at Laboratório de Quimioterapia Experimental em Parasitologia Veterinária, Departamento de Parasitologia Animal do Instituto de Veterinária, Universidade Federal Rural do Rio de Janeiro, Seropédica, RJ, Brazil.

\section{References}

Brasil, Agência Nacional de Vigilância Sanitária - ANVISA. (2006). Guia para provas de biodisponibilidade relativa/bioequivalência de medicamentos (Resolução - $R D C$ no 1,170, de 19 de abril de 2006). Diário Oficial da República Federativa do Brasil, seção 1(101). http://portal.anvisa.gov.br/documents/10181/2718376/\%281\% 29RE_1170_2006_COMP.pdf/52326927-c379-45b4-9a7e-9c5ecabaa16b.

Brasil, Agência Nacional de Vigilância Sanitária - ANVISA. (2012). Dispõe sobre os requisitos mínimos para validação de métodos bioanalíticos empregados em estudos com fins de registro e pós-registro de medicamentos (Resolução - RDC no 27, de 17 de maio de 2012). Diário Oficial da República Federativa do Brasil, seção 1(73). http://portal. anvisa.gov.br/documents/33880/2568070/rdc0027_17_05_2012.pdf/c6edeb56-200d-4482-8a19-99fa11c33fd3.

Brasil. (2019). Brazilian pharmacopeia (6th ed., Vol. 1). São Paulo: Atheneu.

Cerkvenik Flajs, V., \& Grabnar, I. (2002). Ivermectin pharmacokinetics. Slovenian Veterinary Research, 39, 167-178.

Fourie, J. J., Horak, I., Crafford, D., Erasmus, H. L., \& Botha, O. J. (2015). The efficacy treatment of a generic doxycycline tablet in the of canine monocytic ehrlichiosis. Journal of the South African Veterinary Association, 86(1), 1-10. http://dx.doi.org/10.4102/jsava.v86i1.1193. PMid:26018824.

Goodman, G. (2003). As bases farmacológicas da terapêutica (13. ed.). São Paulo: McGraw-Hill.

Gutiérrez, L., Velasco, Z., Vázquez, C., Vargas, D., \& Sumano, H. (2012). Pharmacokinetics of an injectable longacting formulation of doxycycline hyclate in dogs. Acta Veterinaria Scandinavica, 54(1), 35. http://dx.doi. org/10.1186/1751-0147-54-35. PMid:22682068.

Hojman, P., Eriksen, J., \& Gehl, J. (2007). Tet-On inductin with doxycycline after gene transfer in mice: Sweetening of drinking water is not a good idea. Animal Biotechnology, 18(3), 183-188. http://dx.doi. org/10.1080/10495390601105055. PMid:17612841.

Hopkins, A. M., Wojciechowski, J., Abuhelwa, A. Y., Mudge, S., Upton, R. N., \& Foster, D. J. R. (2017). Population pharmacokinetic model of doxycycline plasma concentrations using pooled study data. Antimicrobial Agents and Chemotherapy, 61(3), e02401-e02416. http://dx.doi.org/10.1128/AAC.02401-16. PMid:28052851.

Kaneko, J., Harvey, J., \& Bruss, M. (2008). Clinical biochemistry of domestic animals (6th ed.). Academic Press.

KuKanich, K., \& KuKanich, B. (2015). The effect of sucralfate tablets vs. suspension on oral doxycycline absorption in dogs. Journal of Veterinary Pharmacology and Therapeutics, 38(2), 169-173. http://dx.doi.org/10.1111/jvp.12165. PMid:25233871.

Monsalve, S., Galego, V., Molina, V. M., \& Rodas, J. (2017). Pharmacokintics and adverse effects of doxycycline in the treatment of Ehrlichiosis: theoretical foundations for clinical trials in canines. Revista Mvz Cordoba, $22,6062-6074$

Neer, T. M., Breitschwerdt, E. B., Greene, R. T., \& Lappin, M. R. (2002). Consensus statement on ehrlichial disease of small animals from the infectious disease study group of the ACVIM. Journal of Veterinary Internal Medicine, 16(3), 309-315. http://dx.doi.org/10.1111/i.1939-1676.2002.tb02374.x. PMid:12041661.

Okerman, L., Croubels, S., Cherlet, M., De Wasch, K., De Backer, P., \& Van Hoof, J. (2004). Evaluation and establishing the performance of different screening tests for tetracycline residues in animal tissues. Food Additives and Contaminants, 21(2), 145-153. http://dx.doi.org/10.1080/02652030310001639567. PMid:14754636.

Payne-Johnson, M., Maitland, T. P., Tilt, N., \& Gossellin, J. (2007). An evaluation of the relative palatability of two comercial oral tablets formulations of carprofen and meloxicam in dogs using acceptance and preference tests. Revista Medicina Veterinaria, 158(10), 519-524.

Redelsperger, I. M., Taldone, T., Riedel, E. R., Lepherd, M. L., Lipman, N. S., \& Wolf, F. R. (2016). Stability of doxycycline in feed and water and minimal effective doses in tetracycline-inducible systems. Journal of the American Association for Laboratory Animal Science, 55(4), 467-474. PMid:27423155.

Rinaldi, M. L. (2014). Therapeutic review: doxycycline. Journal of Exotic Pet Medicine, 23(1), 107-112. http://dx.doi. org/10.1053/j.jepm.2013.11.018.

Rudoler, N., Harrus, S., Martinez-Subiela, S., Tvarijonaviciute, A., van Straten, M., Cerón, J. J., \& Baneth, G. (2015). Comparison of the acute phase protein and antioxidant responses in dogs vaccinated against canine monocytic ehrlichiosis and naïve-challenged dogs. Parasites \& Vectors, 8(1), 175. http://dx.doi.org/10.1186/ s13071-015-0798-1. PMid:25888870.

Ruiz, S. M. A., Olvera, L. G., Bernad, M. J. B., \& Estrada, D. V. (2014). Pharmacokinetics of a new oral controlledrelease formulation of doxycycline hyclate for dogs. Asian Journal of Pharmacology \& Toxicology, 2(5), 1-6. 
Sadrieh, N., Brower, J., Yu, L., Doub, W., Straughn, A., Machado, S., Pelsor, F., Martin, E. S., Moore, T., Reepmeyer, J., Toler, D., Nguyenpho, A., Roberts, R., Schuirmann, D. J., Nasr, M., \& Buhse, L. (2005). Stability, dose uniformity, and palatability of three counterrrorism drugs-human subject and electronic tongue studies. Pharmaceutical Research, 22(10), 1747-1756. http://dx.doi.org/10.1007/s11095-005-6387-x. PMid:16180133.

Sainz, Á., Roura, X., Miró, G., Estrada-Peña, A., Kohn, B., Harrus, S., \& Solano-Gallego, L. (2015). Guideline for veterinary practitioners on canine ehrlichiosis and anaplasmosis in Europe. Parasites \& Vectors, 8(1), 75. http://dx.doi.org/10.1186/s13071-015-0649-0. PMid:25649069.

Shargel, L., \& Yu, A. B. C. (2004). Applied biopharmaceutics \& pharmacokinectics. São Paulo: McGraw-Hill.

Skotarczak, B. (2003). Canine ehrlichiosis. Annals of Agricultural and Environmental Medicine, 10(2), 137-141. PMid:14677903.

Song, Y., Peressin, K., Wong, P. Y., Page, S. W., \& Garg, S. (2016). Key considerations in designing oral drug delivery systems for dogs. Journal of Pharmaceutical Sciences, 105(5), 1576-1585. http://dx.doi.org/10.1016/j. xphs.2016.03.007. PMid:27056627.

Thombre, A. G. (2004). Oral delivery of medications to companion animals: Palatability considerations. Advanced Drug Delivery Reviews, 56(10), 1399-1413. http://dx.doi.org/10.1016/j.addr.2004.02.012. PMid:15191789.

Villaescusa, A., García-Sancho, M., Rodríguez-Franco, F., Tesouro, M. Á., \& Sainz, Á. (2015). Effects of doxycycline on haematology, blood chemistry and peripheral blood lymphocyte subssets of healthy dogs and dogs naturally infected with Ehrlichia canis. Veterinary Journal (London, England), 204(3), 263-268. http://dx.doi. org/10.1016/j.tvjl.2015.03.031. PMid:25957920.

Weiss, D. J., \& Wardrop, K. J. (2010). Schalm's veterinary hematology (6th ed.). Ames: Wiley Blackwell. 